\title{
Deferribacter abyssi sp. nov., an anaerobic thermophile from deep-sea hydrothermal vents of the Mid-Atlantic Ridge
}

Correspondence

M. L. Miroshnichenko

alfamirr@mail.ru
M. L. Miroshnichenko, ${ }^{1}$ A. I. Slobodkin, ${ }^{1}$ N. A. Kostrikina, ${ }^{1}$ S. L'Haridon, ${ }^{2}$ O. Nercessian, ${ }^{2}$ S. Spring, ${ }^{3}$ E. Stackebrandt, ${ }^{3}$ E. A. Bonch-Osmolovskaya ${ }^{1}$ and C. Jeanthon ${ }^{2}$

\author{
${ }^{1}$ Institute of Microbiology, Russian Academy of Sciences, Prospekt 60-letiya Oktyabrya 7/2, \\ Moscow 117811, Russia \\ ${ }^{2}$ UMR 6539, Centre National de la Recherche Scientifique and Université de Bretagne \\ Occidentale, Institut Universitaire Européen de la Mer, 29280 Plouzané, France \\ ${ }^{3} \mathrm{DSMZ}$ - Deutsche Sammlung von Mikroorganismen und Zellkulturen, Mascheroder Weg 1b, \\ 38124 Braunschweig, Germany
}

Members of the phylum Deferribacteres are organized into a single class, order and family (Garrity \& Holt, 2001). The family Deferribacteraceae (Huber \& Stetter, 2002) is composed of three genera, Deferribacter, Flexistipes and Geovibrio, which form one separate lineage on the 16SrRNA-based phylogenetic tree with sequence similarity values of around $89 \%$. Currently, the only two species within the genus Deferribacter are Deferribacter thermophilus (Greene et al., 1997) and Deferribacter desulfuricans (Takai et al., 2003). The type species of the genus, $D$. thermophilus, was isolated from the production water of Beatrice oil field, a high-temperature, sea-water-flooded oil reservoir located in the North Sea, UK. The recently described second species of the genus, $D$. desulfuricans, was obtained from a deep-sea

The GenBank accession numbers for the $16 \mathrm{~S}$ rDNA sequences of Deferribacter abyssi strains JR' and DR are AJ515882 and AJ515881, respectively. hydrothermal vent chimney at the Suiyo Seamount in the Izu-Bonin Arc, Japan. Both described species of the genus Deferribacter are strictly anaerobic, thermophilic organisms capable of the oxidation of a variety of complex organic compounds and organic acids in the presence of diverse electron acceptors. In this report, we describe a novel species of this genus, two representatives of which were obtained from two different deep-sea hydrothermal vent fields of the Mid-Atlantic Ridge.

Strains $\mathrm{JR}^{\mathrm{T}}$ and $\mathrm{DR}$ were isolated from hydrothermal samples collected in May 2001 at the Rainbow $\left(36^{\circ} 16^{\prime} \mathrm{N}\right.$, $33^{\circ} 54^{\prime} \mathrm{W}$ ) and Menez Gwen ( $37^{\circ} 50^{\prime} \mathrm{N}, 31^{\circ} 50^{\prime} \mathrm{W}$ ) vent fields of the Mid-Atlantic Ridge. At Rainbow (at a depth of $2400 \mathrm{~m}$ ), an in situ growth chamber or vent cap (Reysenbach et al., 2000) designed to concentrate the micro-organisms discharged by hydrothermal emissions was deployed using the hydraulic arm of the remotely operated vehicle (ROV) Victor. After in situ incubation for 
2 days, the vent cap was closed by the hydraulic arm of the ROV, before transportation to the surface. The fluid from the cap was used in further work. At Menez Gwen (at a depth of $850 \mathrm{~m}$ ), a chimney fragment was collected and placed in an insulated container for the trip to the surface. No temperature measurements were done at either site. Once on board the ship, samples were immediately transferred into $50 \mathrm{ml}$ glass vials and flooded with a sterile solution of $3 \%(\mathrm{w} / \mathrm{v})$ Sea Salts (Sigma). The vials were then closed tightly with butyl-rubber stoppers (Bellco), pressurized with $\mathrm{N}_{2}(100 \mathrm{kPa})$, reduced with sodium sulfide and stored at $4{ }^{\circ} \mathrm{C}$ until further processing at the laboratory.

For the enrichment of organisms, the following basal medium was used $\left(\mathrm{g} \mathrm{l}^{-1}\right.$, unless indicated otherwise): $\mathrm{NH}_{4} \mathrm{Cl}, 0 \cdot 33 ; \mathrm{KCl}, 0 \cdot 33 ; \mathrm{KH}_{2} \mathrm{PO}_{4}, 0.33 ; \mathrm{CaCl}_{2} .2 \mathrm{H}_{2} \mathrm{O}, 0.33$; $\mathrm{MgCl}_{2} \cdot 6 \mathrm{H}_{2} \mathrm{O}, 0 \cdot 33 ; \mathrm{NaCl}, 25 \cdot 0$; yeast extract, $0 \cdot 1 ; \mathrm{NaHCO}_{3}$, 0.3 ; sodium acetate, 2; trace elements (Balch et al., 1979), $10 \mathrm{ml} \mathrm{l}^{-1}$; vitamins (Wolin et al., 1963), $10 \mathrm{ml} \mathrm{l}^{-1}$. Elemental sulfur $\left(10 \mathrm{~g} \mathrm{l}^{-1}\right)$ or nitrate $\left(2 \mathrm{~g} \mathrm{l}^{-1}\right)$ was added as the electron acceptor. The media were prepared anaerobically and dispensed into $17 \mathrm{ml}$ Hungate tubes; the headspace $(7 \mathrm{ml})$ was filled with $\mathrm{N}_{2}$. The $\mathrm{pH}$ of the media before sterilization was $6 \cdot 5$.

After 3-5 days incubation at $60^{\circ} \mathrm{C}$, abundant growth of motile, straight- to vibrio-shaped organisms was detected in both types of enrichment medium. From the enrichment on sulfur-containing medium, strain $\mathrm{JR}^{\mathrm{T}}$ was obtained by the agar-shake dilution technique in the same basal medium supplemented with polysulfides (Widdel \& Pfennig, 1992) and solidified with $1.5 \%$ agar (Difco). Strain DR was obtained by the same technique, but on the solid medium supplemented with sodium nitrate $\left(1 \mathrm{~g} \mathrm{l}^{-1}\right)$ from the corresponding enrichment.

Strain $\mathrm{JR}^{\mathrm{T}}$ was studied in detail. Cells of this strain were small rods of about $1 \cdot 5-2 \mu \mathrm{m}$ in length and $0 \cdot 4-0 \cdot 5 \mu \mathrm{m}$ in width, which occurred singly, in pairs or in small chains. They were motile by means of one polar flagellum (Fig. 1a). In the stationary phase of growth, some rods took a spherical shape. Spores were never observed. Thin sections (BonchOsmolovskaya et al., 1990) revealed that the cell wall of strain $\mathrm{JR}^{\mathrm{T}}$ had a typical Gram-negative structure (Fig. 1b). Strain $\mathrm{JR}^{\mathrm{T}}$ grew over a temperature range of $45-65^{\circ} \mathrm{C}$, with optimal growth observed at $60^{\circ} \mathrm{C}$. At $60^{\circ} \mathrm{C}$, the strain grew between $\mathrm{pH} 6 \cdot 0$ and $7 \cdot 2$, with an optimum around $\mathrm{pH} 6 \cdot 5$. Strain $\mathrm{JR}^{\mathrm{T}}$ required $\mathrm{NaCl}$ for growth and grew at $\mathrm{NaCl}$ concentrations ranging from 10 to $50 \mathrm{~g} \mathrm{l}^{-1}$, with an optimum at $30 \mathrm{~g} \mathrm{NaCl} \mathrm{l}^{-1}$. When air was added to the headspace of the tubes filled with basal medium $(5 \mathrm{ml})$, supplemented with $2 \mathrm{~g}$ yeast extract $1^{-1}$ and elemental sulfur, up to final oxygen concentrations of $0 \cdot 1-1 \%$, no growth of strain $\mathrm{JR}^{\mathrm{T}}$ was observed.

Strain $\mathrm{JR}^{\mathrm{T}}$ was found to grow using acetate, pyruvate, succinate, yeast extract, tryptone, peptone, Bio-trypticase, Bacto-tryptone ( $2 \mathrm{~g} \mathrm{l}^{-1}$, organic acids as their sodium salts) and molecular hydrogen $\left[\mathrm{H}_{2} / \mathrm{CO}_{2}(8: 2, \mathrm{v} / \mathrm{v}\right.$, atmospheric

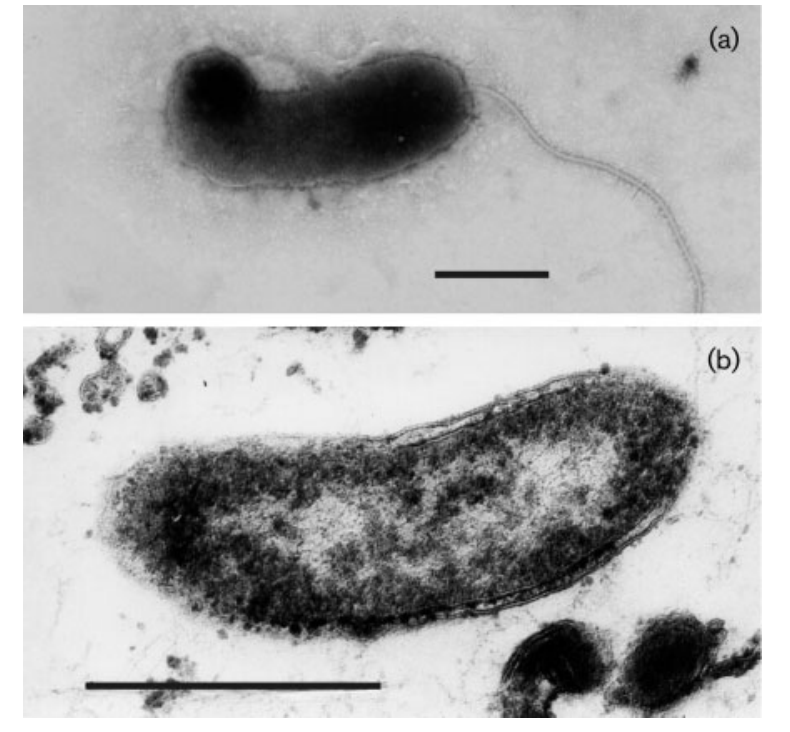

Fig. 1. Negatively stained whole cell (a) and thin-sectioned cell (b) of strain $\mathrm{JR}^{\top}$. Bars, $0.5 \mu \mathrm{m}$.

pressure)] as electron donors, and sulfur or nitrate as electron acceptors. It was not able to utilize glucose, sucrose, xylose, lactose, fructose, starch, methanol, ethanol, formate, propionate, butyrate, malate with or without sulfur $\left(10 \mathrm{~g} \mathrm{l}^{-1}\right)$ or nitrate (sodium salt, $1 \mathrm{~g} \mathrm{l}^{-1}$ ). Elemental sulfur was reduced to hydrogen sulfide (Trüper \& Schlegel, $1964)$ in the course of sulfur reduction. Nitrate was reduced to nitrite; $\mathrm{NO}, \mathrm{N}_{2} \mathrm{O}$ or ammonium were not detected by methods described elsewhere (Miroshnichenko et al., 2003c). The doubling time under the optimal growth conditions, on the medium with yeast extract and elemental sulfur, was around $55 \mathrm{~min}$, with the final cell concentration exceeding $10^{8}$ cells $\mathrm{ml}^{-1}$. No growth on fermentable substrates occurred in the absence of electron acceptors. Strain $\mathrm{JR}^{\mathrm{T}}$ could also grow chemolithoautotrophically on the basal medium in the absence of yeast extract, using molecular hydrogen as the electron donor, sulfur or nitrate as electron acceptors and $\mathrm{CO}_{2}$ as the carbon source. The strain was also shown to be able to grow with amorphous $\mathrm{Fe}(\mathrm{III})$ oxide $(90 \mathrm{mM})$ (Slobodkin et al., 1999) or Fe(III) citrate $(20 \mathrm{mM})$ as electron acceptors and acetate, succinate or molecular hydrogen as electron donors with approximately the same doubling time and cell yield as with other electron acceptors. Growth of strain $\mathrm{JR}^{\mathrm{T}}$ with molecular hydrogen and amorphous $\mathrm{Fe}(\mathrm{III})$ oxide was, however, possible only in the presence of yeast extract $\left(50 \mathrm{mg} \mathrm{l^{-1 }}\right.$ minimal concentration). Amorphous $\mathrm{Fe}(\mathrm{III})$ oxide was reduced to a black magnetic precipitate with a high Fe(II) content. Sulfate, thiosulfate, nitrite, malate (sodium salts, $1 \mathrm{~g} \mathrm{l}^{-1}$ ) and $\mathrm{Mn}(\mathrm{IV})$ supplied as $20 \mathrm{mM}$ of $\mathrm{MnO}_{2}$ were not used as electron acceptors and did not support the growth on any of the substrates. Growth of strain $\mathrm{JR}^{\mathrm{T}}$ was inhibited by chloramphenicol, penicillin, rifampicin, streptomycin but not by tetracycline (all tested at a concentration of 
$100 \mu \mathrm{g} \mathrm{ml} \mathrm{g}^{-1}$ at $\left.60^{\circ} \mathrm{C}\right)$. Because of its unstable growth, strain DR was characterized only tentatively. Nevertheless, it was found to have the same morphology, optima and ranges of $\mathrm{pH}$, temperature and salinity and used the same electron acceptors as strain $\mathrm{JR}^{\mathrm{T}}$.

The $\mathrm{G}+\mathrm{C}$ content of strain JR ${ }^{\mathrm{T}} \mathrm{DNA}$, determined according to Miroshnichenko et al. (1994), was $30 \cdot 8 \mathrm{~mol} \%$. Analysis of the almost-complete $16 \mathrm{~S}$ rRNA gene sequences of strains $\mathrm{JR}^{\mathrm{T}}$ and DR (1517 nucleotides), done as described previously (Rainey et al., 1995; Maidak et al., 2001; Jukes \& Cantor 1969), indicated that their 16S sequences were identical and $95 \cdot 3$ and $95 \cdot 2 \%$ similar to those of $D$. thermophilus $\mathrm{BMA}^{\mathrm{T}}$ and $D$. desulfuricans DSM $14783^{\mathrm{T}}$, respectively. The binary similarity value for the latter two strains was $97.9 \%$. A phylogenetic dendrogram (Fig. 2), displaying the position of strain $\mathrm{JR}^{\mathrm{T}}$ in relation to the two described species of the genus Deferribacter, was reconstructed from a distance matrix using the treeing algorithm of De Soete (1983). Most branching points are supported by high bootstrap values. The three Deferribacter species were distantly related to Flexistipes sinusarabici DSM $4947^{\mathrm{T}}$ (87·1-87.6\% sequence similarity), the two species of Geovibrio (84.6-85.9\% sequence similarity) and Denitrovibrio acetiphilus $\mathrm{N} 2460^{\mathrm{T}}(83 \cdot 3-84 \cdot 4 \%$ sequence similarity).

Enrichment and isolation experiments performed with samples collected from deep-sea hydrothermal fluids and chimneys initially revealed the predominance of sulfurreducing thermophiles. Recent culture and isolation studies

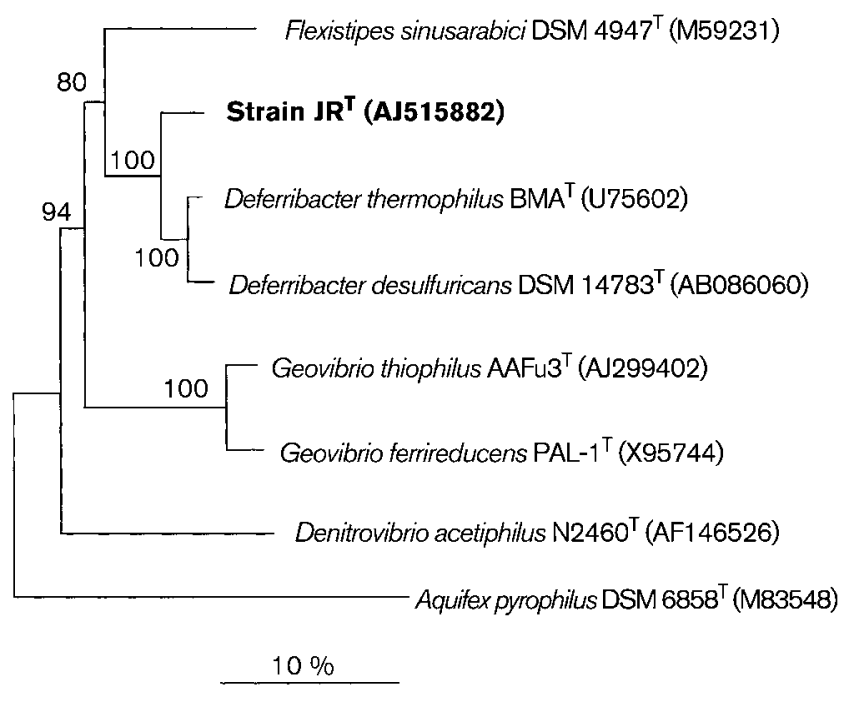

Fig. 2. Phylogenetic position of strain $J R^{\top}$ within the family Deferribacteraceae. The dendrogram is derived from a neighbourjoining analysis of almost-complete 16S rRNA gene sequences. Numbers at branching points are bootstrap values (expressed as percentages of 500 resamplings). The $16 \mathrm{~S}$ rRNA gene sequence of Aquifex pyrophilus was used as an outgroup. Bar, estimated sequence divergence. have, however, reported that nitrate and Fe(III) may also represent alternative electron acceptors widely used by phylogenetically diverse organisms in these environments. Many of the newly discovered thermophilic prokaryotes inhabiting deep-sea hydrothermal vents have been shown to be capable of denitrification. Representatives of the family Thermaceae, Oceanithermus profundus and Vulcanithermus mediatlanticus (Miroshnichenko et al., 2003a, b), are able to reduce nitrate to nitrite, members of the genus Persephonella (Götz et al., 2002) are able to produce nitrogen in the course of nitrate reduction, whereas Caldithrix abyssi (Miroshnichenko et al., 2003c), Caminibacter hydrogeniphilus (Alain et al., 2002) and Thermovibrio ruber (Huber et al., 2002) are able to reduce nitrate to ammonium as the end product of denitrification. The presence in deep-sea hydrothermal vents of thermophilic dissimilatory $\mathrm{Fe}$ (III)reducing micro-organisms, including representatives of the genus Deferribacter, was first demonstrated by denaturinggradient gel electrophoresis (DGGE) experiments performed on enrichment cultures (Slobodkin et al., 2001). However, to date, the archaeon Geoglobus ahangari (Kashefi et al., 2002) is the only example of a deep-sea hydrothermal vent micro-organism that is capable of dissimilatory $\mathrm{Fe}(\mathrm{III})$ reduction in growing cultures. Strain $\mathrm{JR}^{\mathrm{T}}$, one of the new isolates described in this report, represents another group of micro-organisms inhabiting deep-sea hydrothermal vents moderately thermophilic bacteria able to reduce Fe(III) compounds as well as nitrate and sulfur. Strain $\mathrm{JR}^{\mathrm{T}}$ shares many common phenotypic features with the type species of the genus Deferribacter, D. thermophilus (Table 1). However, strain $\mathrm{JR}^{\mathrm{T}}$ differs from $D$. thermophilus and $D$. desulfuricans by its ability to grow lithoautotrophically, utilizing hydrogen as an electron donor, $\mathrm{CO}_{2}$ as a carbon source and elemental sulfur or nitrate as electron acceptors.

Table 1. Characteristics useful for differentiating strain $J R^{\top}$ from other Deferribacter spp.

Strain/species: 1, strain $\mathrm{JR}^{\mathrm{T}} ; 2$, D. thermophilus (Greene et al., 1997); 3, D. desulfuricans (Takai et al., 2003). +, Positive; - , negative.

\begin{tabular}{|lccc|}
\hline Characteristic & $\mathbf{1}$ & $\mathbf{2}$ & $\mathbf{3}$ \\
\hline Temperature range $\left({ }^{\circ} \mathrm{C}\right)$ & $45-65$ & $50-65$ & $40-70$ \\
Optimal temperature $\left({ }^{\circ} \mathrm{C}\right)$ & 60 & 60 & $60-65$ \\
Electron acceptor: & & & \\
$\quad$ Elemental sulfur & + & - & + \\
Fe(III) & + & + & - \\
Mn(IV) & - & + & - \\
Electron donor: & & & \\
Ethanol & - & - & + \\
Formate & - & - & + \\
Propionate & - & - & + \\
Pyruvate & + & - & + \\
Lithoautotrophic growth & + & - & - \\
G + C content (mol\%) & $30 \cdot 8$ & 34 & $38 \cdot 6$ \\
\hline
\end{tabular}


Other significant characteristics that differentiate strain $\mathrm{JR}^{\mathrm{T}}$ from $D$. thermophilus are its ability to reduce sulfur and inability to use $\mathrm{Mn}(\mathrm{IV})$ as an electron acceptor. In contrast to $D$. desulfuricans, strain $\mathrm{JR}^{\mathrm{T}}$ is able to reduce $\mathrm{Fe}(\mathrm{III})$. On the basis of the results of phylogenetic, genosystematic and physiological studies that clearly differentiate strain $\mathrm{JR}^{\mathrm{T}}$ from known species of the genus Deferribacter, we propose to describe it as the type strain of a new species of the genus, namely, Deferribacter abyssi. Strain DR (=DSM 14927) represents the second strain of the same species.

\section{Description of Deferribacter abyssi sp. nov.}

Deferribacter abyssi (a.bys'si. L. fem. gen. n. abyssi of immense depths, living in the depths of the ocean).

Small rods that are straight- to vibrio-shaped. Cells are $1 \cdot 5-2 \cdot 0 \mu \mathrm{m}$ long and $0 \cdot 4-0 \cdot 5 \mu \mathrm{m}$ wide, with the Gramnegative type of cell wall. Motile by means of one polar flagellum. Anaerobic. Moderately thermophilic, growing between 45 and $65^{\circ} \mathrm{C}$, with optimum growth at $60^{\circ} \mathrm{C}$. Neutrophilic, growing between $\mathrm{pH} 6 \cdot 0$ and $7 \cdot 2$, with optimum growth at $\mathrm{pH} 6 \cdot 5-6 \cdot 7$. Grows at $\mathrm{NaCl}$ concentrations ranging from 10 to $50 \mathrm{~g} \mathrm{l}^{-1}$, with optimum growth at $30 \mathrm{~g} \mathrm{NaCl}^{-1}$. Capable of chemolithoautotrophic growth with hydrogen as an electron donor, elemental sulfur or nitrate as electron acceptors and $\mathrm{CO}_{2}$ as a carbon source. Anaerobic oxidation of acetate, pyruvate, succinate and proteinaceous substrates by using sulfur, nitrate or $\mathrm{Fe}(\mathrm{III})$ as electron acceptors. Not capable of fermentation. Sensitive to rifampicin, chloramphenicol, vancomycin, penicillin and streptomycin but resistant to tetracycline. Isolated from hydrothermal vent fields of the Mid-Atlantic Ridge.

The type strain is $\mathrm{JR}^{\mathrm{T}}\left(=\mathrm{DSM} 14873^{\mathrm{T}}=\mathrm{JCM} 11955^{\mathrm{T}}\right)$. The $\mathrm{G}+\mathrm{C}$ content of its DNA is $30 \cdot 8 \mathrm{~mol} \%$. Isolated from the Rainbow ( $36^{\circ} 16^{\prime} \mathrm{N}, 33^{\circ} 54^{\prime} \mathrm{W}$ ) hydrothermal vent field of the Mid-Atlantic Ridge.

\section{Acknowledgements}

We thank Yves Fouquet (chief scientist) for inviting us to participate in the Iris cruise (2001) and the crews of the remote vehicle L'Atalante and the pilots of the remotely operated vehicle Victor. This work was supported by a CNRS/Rhône-Poulenc grant, a PRIR grant from the Conseil Régional de Bretagne, INTAS grants 99-1250 and 011-0151, RFBR grant 00-04-48924 and CRDF grant RB2-2379-MO-02. M. L. M. was supported by the Ministère de l'Education Nationale during her stay in France.

\section{References}

Alain, K., Querellou, J., Lesongeur, F., Pignet, P., Crassous, P., Raguénès, G., Cueff, V. \& Cambon-Bonavita, M.-A. (2002). Caminibacter hydrogeniphilus gen. nov., sp. nov., a novel thermophilic, hydrogen-oxidizing bacterium isolated from an East Pacific Rise hydrothermal vent. Int J Syst Evol Microbiol 52, 1317-1323.

Balch, W. E., Fox, G. E., Magrum, L. J., Woese, C. R. \& Wolfe, R. S. (1979). Methanogens: reevaluation of a unique biological group. Microbiol Rev 43, 260-296.
Bonch-Osmolovskaya, E. A., Sokolova, T. G., Kostrikina, N. A. \& Zavarzin, G. A. (1990). Desulfurella acetivorans gen. nov., sp. nov. - a new thermophilic sulfur-reducing eubacterium. Arch Microbiol 153, 151-155.

DeSoete, G. (1983). A least squares algorithm for fitting additive trees to proximity data. Psychometrika 48, 621-626.

Garrity, G. M. \& Holt, J. M. (2001). Phylum BIX. Deferribacteres phy. nov. In Bergey's Manual of Systematic Bacteriology, 2nd edn, vol. 1, p. 465. Edited by D. R. Boone \& R. W. Castenholz. New York: Springer.

Götz, D., Banta, A., Beveridge, T. G., Rushdi, A. I., Simoneit, B. R. T. \& Reysenbach, A.-L. (2002). Persephonella marina gen. nov., sp. nov. and Persephonella guaymasensis sp. nov., two novel, thermophilic, hydrogen-oxidizing microaerophiles from deep-sea hydrothermal vents. Int J Syst Evol Microbiol 52, 1349-1359.

Greene, A. C., Patel, B. K. C. \& Sheehy, A. J. (1997). Deferribacter thermophilus gen. nov., sp. nov., a novel thermophilic manganeseand iron-reducing bacterium isolated from a petroleum reservoir. Int $J$ Syst Bacteriol 47, 505-509.

Huber, H. \& Stetter, K. O. (2002). Family I. Deferribacteraceae fam. nov. In Bergey's Manual of Systematic Bacteriology, 2nd edn, vol. 1, pp. 465-466. Edited by D. R. Boone \& R. W. Castenholz. New York: Springer.

Huber, H., Diller, S., Horn, C. \& Rachel, R. (2002). Thermovibrio ruber gen. nov., sp. nov., an extremely thermophilic, chemolithoautotrophic, nitrate-reducing bacterium that forms a deep branch within the phylum Aquificae. Int J Syst Evol Microbiol 52, 1859-1865.

Jukes, T. H. \& Cantor, C. R. (1969). Evolution of protein molecules. In Mammalian Protein Metabolism, pp. 21-132. Edited by H. N. Munro. New York: Academic Press.

Kashefi, K., Tor, J. M., Holmes, D. E., Gaw Van Praagh, C. V., Reysenbach, A.-L. \& Lovley, D. R. (2002). Geoglobus ahangari gen. nov., sp. nov., a novel hyperthermophilic archaeon capable of oxidizing organic acids and growing autotrophically on hydrogen with $\mathrm{Fe}$ (III) serving as the sole electron acceptor. Int J Syst Evol Microbiol 52, 719-728.

Maidak, B. L., Cole, J. R., Lilburn, T. G. \& 7 other authors (2001). The RDP-II (Ribosomal Database Project). Nucleic Acids Res 29, 173-174.

Miroshnichenko, M. L., Gongadze, G. A., Lysenko, A. M. \& BonchOsmolovskaya, E. A. (1994). Desulfurella multipotens sp. nov., a new sulfur-respiring thermophilic eubacterium from Raoul Island (Kermadec archipelago, New Zealand). Arch Microbiol 161, 88-93.

Miroshnichenko, M. L., L'Haridon, S., Jeanthon, C. \& 7 other authors (2003a). Oceanithermus profundus gen. nov., sp. nov., a thermophilic, microaerophilic, facultatively chemolithoheterotrophic bacterium from a deep-sea hydrothermal vent. Int $J$ Syst Evol Microbiol 53, 747-752.

Miroshnichenko, M. L., L'Haridon, S., Nercessian, O. \& 8 other authors (2003b). Vulcanithermus mediatlanticus gen. nov., sp. nov., a novel member of the family Thermaceae from a deep-sea hot vent. Int J Syst Evol Microbiol 53, 1143-1148.

Miroshnichenko, M. L., Kostrikina, N. A., Chernyh, N. A., Pimenov, N. V., Tourova, T. P., Antipov, A. N., Spring, S., Stackebrandt, E. \& Bonch-Osmolovskaya, E. A. (2003c). Caldithrix abyssi gen. nov., sp. nov., a nitrate-reducing, thermophilic, anaerobic bacterium isolated from a Mid-Atlantic Ridge hydrothermal vent, represents a novel bacterial lineage. Int J Syst Evol Microbiol 53, 323-329.

Rainey, F. A., Weiss, N. \& Stackebrandt, E. (1995). Phylogenetic analysis of the genera Cellulomonas, Promicromonospora, and Jonesia and proposal to exclude the genus Jonesia from the family Cellulomonadaceae. Int J Syst Bacteriol 45, 649-652. 
Reysenbach, A.-L., Longnecker, K. \& Kirshtein, J. (2000). Novel bacterial and archaeal lineages from an in situ growth chamber deployed at a Mid-Atlantic Ridge hydrothermal vent. Appl Environ Microbiol 66, 3798-3806.

Slobodkin, A., Campbell, B., Cary, S. C., Bonch-Osmolovskaya, E. \& Jeanthon, C. (2001). Evidence for the presence of thermophilic $\mathrm{Fe}(\mathrm{III})$-reducing microorganisms in deep-sea hydrothermal vents at $13^{\circ} \mathrm{N}$ (East Pacific Rise). FEMS Microbiol Ecol 36, 235-243.

Slobodkin, A. I., Tourova, T. P., Kuznetsov, B. B., Kostrikina, N. A., Chernyh, N. A. \& Bonch-Osmolovskaya, E. A. (1999). Thermoanaerobacter siderophilus sp. nov., a novel dissimilatory $\mathrm{Fe}(\mathrm{III})$ reducing, anaerobic, thermophilic bacterium. Int J Syst Bacteriol 49, 1471-1478.
Takai, K., Kobayashi, H., Nealson, K. H. \& Horikoshi, K. (2003). Deferribacter desulfuricans sp. nov., a novel sulfur-, nitrate- and arsenate-reducing thermophile isolated from a deep-sea hydrothermal vent. Int J Syst Evol Microbiol 53, 839-846.

Trüper, H. G. \& Schlegel, H. G. (1964). Sulfur metabolism in Thiorhodaceae. I. Quantitative measurements on growing cells of Chromatium okenii. J Microbiol Serol 30, 225-232.

Widdel, F. \& Pfennig, N. (1992). The genus Desulfuromonas and other gram-negative sulfur-reducing eubacteria. In The Prokaryotes, 2nd edn, vol. 1, pp. 3379-3389. Edited by A. Balows, H. G. Trüper, M. Dworkin, W. Harder, K. H. Schleifer. New York: Springer.

Wolin, E. A., Wolin, M. J. \& Wolfe, R. S. (1963). Formation of methane by bacterial extracts. J Biol Chem 238, 2882-2888. 